\title{
The Lysterfield Avenue of Honour
}

\author{
Shaun Patrick Kenaelly
}

7 The Lysterfield district extends along a valley between the southern ridge of the Blue Dandenong ranges (East of Melbourne) and the low Lysterfield hills.

1 These fall away toward the industrial city of Dandenong and the very new suburban estates around Endeavour Hills and Rowville. At points the transition is abrupt. The hills were heavily quarried until the 1970 s, but the valley itself remains pastoral: a mixture of grazing and intensive market gardening. It sent twelve men to the Great War; two did not come back. We know this thanks to the presence of a war memorial: an avenuie of honour down Lysterfield road, from the junction of Wellington road. A local landowner, Gus Powell, acting on his own initiative and working at his own expense, planted the avenue of trees and dedicated it as an Anzac memorial, in September 1919.

Gus Powell chose his trees with an eye to their symbolism. There is a tree for each man. The furst two were English Oak (Quercus robur), standing for the men who had fallen: G. M. Reid (missing in action, Fleurbaix, July 19, 1916), and Gunner R. W. Moors (died of wounds, July 25, 1916). Moors had enlisted under a false name and was perhaps under age. A brother is represented elsewhere in the avenue. The remainder of the trees were Silky Oak (Grevillea robusta), an interesting association of European and Australian trees. Silky Oak is not native to the district, but is a fine plantation tree. There were tree guards bearing the individual names and the first oak also carried a memorial plaque:

\author{
ERECTED BY \\ GUS POWELL \\ IN HONOR \\ OF THOSE \\ WHO SERVED \\ THE EMPIRE \\ IN THE \\ GREAT WAR \\ $1914-1919$
}

LYSTERFIELD, 13TH. SEPT. 1919.

Most places can boast similar memorials. Within five miles of this are - or were - half-a-dozen Anzac avenues. Not all have survived the chances of the years. The Lysterfield avenue is of wider interest because of its subsequent history and because we know what that history was. Unlike the more enduring monuments of stone, the 
avenues have not generally enjoyed luck. The trees were planted, grew - and were gradually forgotten. Some were felled in road-widening schemes, others lopped as power-lines were strung above their heads. The Lysterfield avenue earned a brief mention in a volume of Shire history published in 1958, but otherwise grew out of memory and keeping as the years passed by. At the end of the 1970s it lay in neglect. Some of the trees were gone and others missing their names. The plaque was concealed by undergrowth. But it was not entirely forgotten.

In 1978, learning of a plan to widen the road, Mrs Heather Ronald, granddaughter of Gus Powell, rescued the plaque and commenced to lobby for preservation and restoration of the avenue. There was much in the way of letter-writing. She contacted the historical society and the Shire Council. Lt Col R. A. Gordon, of Upwey-Belgrave RSL, joined the campaign and military archives were consulted for the service details of the twelve men. The Shire engineer gave his advice and Council accepted it. All of which sounds easy, but it took six years. A cairn, of local bluestone, was erected and Mrs Ronald provided a new plaque. The wording followed the spirit of the old, but in simpler lines and now including the names, ranks and units of the men. The Lysterfield avenue of honour was re-dedicated, 10 November 1984.

The forgetting was swifter. After ten years, the avenue was again found in a sorry state. The cairn was buried under a tangle of blackberry and bracken. No one had thought to maintain it. Then it was remembered. Returned soldiers approached Council and the local newspaper. The Shire voted to clean up the area and the newspaper editorialised about the value of heritage. All of which was dutifully done and said - and which, presumably, will happen all over again in another decade or so. Here is the problem in a nutshell. Simply, who owns the avenue? Who is to take responsibility for it? Is this a civic, corporate, or private matter?

The press reports were full of howlers (one had Gus Powell as one of the twelve men and Mrs Ronald's great-grandfather), and the Shire did the clearing as a 'gesture to community feeling', thus avoiding direct responsibility: a responsibility, to be fair, it probably did not possess in the first place. Trees and cairn stand on a road reserve, where Council does have an interest; but establishment and renewal were a matter of private initiative. Groups like the RSL and the historical societies do have a legitimate interest, but it is hardly theirs. Nor did Gus Powell leave the stewardship to his own posterity. It was a civic and patriotic gesture on his part and a fine one, given to district and nation in the aftermath of a profound historical drama. It follows that if anyone does have title, then it would be the spirit of the nation and not any of its particular agencies at any given historical point.

Gus Powell was not a constitutional lawyer. But he was probably right to trust to the spirit of the laws. There is one fixed point in the year where the spirit of the nation is made tangible: on Anzac Day, when in town and country, ceremonies and services are conducted at war memorials, all in the assumption that cenotaph, statue or tree belong to our known past, the unseen future, and to us, very much so, as we stand respectfully in the present. Over the longer term this tangible spirit is likely to arise, at intervals, to remember the Lysterfield avenue of honour at need and to take up its cause before the appropriate authorities. In other words, a Gus Powell or two in every 
generation. In so doing, they will undoubtedly appeal to the authority of that spirit, which rests upon tradition, sentiment and usage. It is an authority existing prior to and above the practical question of who is going to cut the grass.

It would be far easier were some single authority take full responsibility for the avenue. But that carries the risk of interference. Without doubt, the best guarantee for the future of the avenue lies in usage. Anzac and Armistice Day ceremonies deserve to be conducted there. Once or twice a year, people will be able to check upon the condition of the place, re-establishing possession, as it were. Otherwise, the next chapter in the story seems fairly clear. Suburban pressure is building up on the Lysterfield valley, with conservationists resisting it. What will probably result is a compromise of estate-housing and green belt. At some point (the centenary, 2015?), the new residents will rediscover the Lysterfield avenue of honour and recognise it as the one sure link with the old district and providing the continuity of a historical past. Certain of their title they will claim it as their own.

S. P. Kenaelly is a private scholar. 